\title{
The Effect of Self-efficacy on Intermediate EFL Learner's Reading Comprehension Improvement: Evidence from Iranian English Learners
}

\author{
Mohammad Javad Tandiseh ${ }^{1,2, \text { * }, \text { Masood Baqeri }}{ }^{1,3}$ \\ ${ }^{1}$ Department of Foreign Languages and Linguistics, Arak University, Arak, Iran \\ ${ }^{2}$ Science and Research Branch, Islamic Azad University, Tehran, Iran \\ ${ }^{3}$ Science and Research Branch of Bushehr, Islamic Azad University, Tehran, Iran \\ Email address: \\ Javadtandiseh $a$ yahoo.com (M. J. Tandiseh), M.bagheritrragmail.com (M. Baqeri) \\ *Corresponding author
}

\section{To cite this article:}

Mohammad Javad Tandiseh, Masood Baqeri. The Effect of Self-efficacy on Intermediate EFL Learner's Reading Comprehension Improvement: Evidence from Iranian English Learners. Communication and Linguistics Studies. Vol. 5, No. 4, 2019, pp. 74-79. doi: $10.11648 /$ j.cls.20190504.11

Received: July 26, 2019; Accepted: October 9, 2019; Published: December 19, 2019

\begin{abstract}
This study was an attempt to examine the effect of self-efficacy on Iranian EFL learners' reading comprehension. Reading comprehension plays a significant role in educational success. In spite of its importance, students still have difficulties in understanding texts. One solution to the problem of poor reading comprehension is the learning of reading strategies. The current study examined the effect of summarizing strategy on reading comprehension of Iranian intermediate EFL learners. Pretest-posttest design was employed to scrutinize the possible improvements of two classes of intermediate English learners (one experimental and one control group) as reading comprehension was concerned. Two groups were exposed to the same reading test as the pre and the post-test, however, only the experimental groups received the special treatment regarding to promote their self-efficacy. After the application of the study's treatment, data analysis process initiated which indicated that experimental groups who received treatment had a better performance than the control group on the final reading test. In addition, the findings suggested that self-efficacy were same in male and female participants. The findings of the study indicated that summarizing strategy has a significant effect on learners' reading comprehension. Generally, the findings imply that self-efficacy can positively affect the reading comprehension ability of the intermediate EFL learners.
\end{abstract}

Keywords: Self-efficacy, Reading Comprehension, EFL Learner

\section{Introduction}

English language plays a fundamental role in modern world. Although the information is recorded in many world languages, one of the most widespread of those languages is English. In a world of information and technology, reading has become one of the most crucial language skills for both the educational and business worlds. Because reading is observed as one of the most important educational skills for second or foreign learners, learners are required to read a considerable number of texts in English. Not only do they have to read for comprehension, but also they have to read with significant speed. Since the reading comprehension is complicated skill, researchers and teachers should be concentrated on this skill in their work. Reading is the most difficult activity that involves orthographic, phonological, syntactic and semantic processing; i.e., bottom-up processing, background knowledge and top-down processing [1]. Selfefficacy as one of the most important affective factors influences emotional sides of learners. It plays an important role in language learning and motivates students efficiently. Many researchers stated a significant relationship between language learning and self-efficacy. In the language learning process, learners with high self- efficacy participate in tasks more rapidly, work harder, and persist longer when 
encountering failures than those who doubt their own capabilities [2]. Consequently, EFL learners should believe in their abilities and make greater efforts when encountering failures rather than to attribute all their failures to their lack of abilities.

\section{Literature Review}

Recently vast changes have appeared in the field of foreign language acquisition research. Researchers have focused on how people can learn a foreign language more proficiently. Importance in EFL has shifted from the teachers' teaching to learners' learning. According to this change in EFL, most of the studies have been from the learner's perspective. Researchers have identified some individual learner variables that affect learning outcomes such as learning style, age, self-efficacy beliefs, aptitude, motivation, educational experience and learning strategies. Among them self-efficacy belief is more focused topics. Bandura [3], one of the first to undertake research in this area, defined self-efficacy as an individual's belief in his or her ability to perform a specific task or behavior. Selfefficacy is not a general quality possessed by individuals, but rather specific beliefs an individual may have around particular tasks or behaviors [4]. Nearly two decades of research revealed that self-beliefs are strong predictors of academic achievements so that a new wave of educational psychologists are calling for attention to self-beliefs related to their academic pursuits [5]. Of all beliefs, self-efficacy is the most influential arbiter in human agency and plays powerful role in determining the choices people make, the effort they will persevere in the face of challenge, and the degree of anxiety or confidence they will bring to the task at hand [6]. It is this perceived self- efficacy that helps explain why people's behaviors differ widely even when they have similar knowledge and skills. Several researchers have conducted studies on the relationship between selfefficacy concept and language related skills. Wigfield [7] examined the effect of self-efficacy on school students' achievement in math and English at the beginning and end of school year. The results of their study indicated that selfefficacy was a strong predictor of math and English achievement. Examining the relationship between selfefficacy and use of language learning strategies among ESL pre service teachers in Malaysia, Siew and Wong [8] found that teachers with higher degrees of self-efficacy reported to use language learning strategies more frequently than those with lower levels of self-efficacy. EFL learners with high self-efficacy know how to improve their reading comprehension because their teacher is self-efficacious and guides them how to use reading comprehension strategies effectively. Hosenfeld [9] believed successful readers helped the meaning of the passage in mind while reading, read in broad, and skipped inconsequential or less important words. Rubin [10], Wenden [11] and Oxford [12] as cited in Shang [13] state that a good reader becomes an active participant in the reading process; one who requires the integration and application of multiple strategies while reading. This is also where good readers and poor readers can be distinguished from each other in terms of their control over strategy use. Tilfarlioglu and cgnkara [14] investigated the self-efficacy of EFL learners enrolled at Gaziantep University's school of foreign languages (GUSFL). In this study, 175 preparatory learners participated. The data were collected through the English as a foreign language self-efficacy questionnaire. The study showed that EFL learners at GUSFL had a strong sense of self efficacy in language learning tasks. Li and Wang [15] explored the relationship between self-efficacy and the use of reading comprehension strategies. Participants were 182 sophomore English students. Results revealed that reading self-efficacy was significantly related to the use of reading comprehension strategies in general. Readers with high self-efficacy reported significantly more use of reading strategies than those with low self-efficacy. Shang [16] investigated the relationship between EFL proficiency level and reading strategy use. Findings showed that there was a positive relationship between reading strategy use and perceptions of self-efficacy. Rahimi, Riazi, and Saif [17] did a study about factors influencing the use of language learning strategies by Persian EFL learners. Their results showed proficiency level and motivation as major predictors of language learning strategies use. Also, gender had not any effect on the performance of the students. Naseri and Zaferanieh [18], in a study, found the relationship between reading self-efficacy beliefs, reading strategy use and reading comprehension level of Iranian EFL learners. Michigan reading comprehension test, a selfreported reading strategy use questionnaire, and a reading self-efficacy questionnaire were administered to eighty junior and senior EFL students. Findings showed that there were significant strong positive correlation between reading self-efficacy beliefs and reading comprehension and also between reading self-efficacy beliefs and reading strategy use. Magogwe and Oliver [19], in their study, investigated that learners differed from each other with respect to their reading comprehension ability, reading self-efficacy beliefs and the use of reading comprehension strategies. This study showed that the relationship between reading self-efficacy beliefs and reading strategy use was not affected by gender. Poole [20], in a study, compared the academic reading comprehension strategies of 248 (138 male and 110 female) advanced college ESL students. Findings showed very few strategic differences between male and female students regarding the use of strategies. He explored that ESL readers were affected by factors other than gender. Ghezlou, Kordi and Nasrabady [21] investigated gender differences in reading strategy use, reading self- efficacy, and perceptual learning styles among EFL learners. In this study, 127 sophomore EFL students participated. The findings showed that gender did not have any significant effect on the performance of Iranian high intermediate EFL learners. 


\section{Method}

\subsection{Participant}

The participants of the study were 36 intermediate students both males and females (17 Male, 19 Female) in Arman institute in Ahvaz. They were Iranian EFL learners that study New Interchange and their age ranges are from 13 to 16. After administration of OPT test, 36 intermediate students were selected. They were divided into two groups.

Table 1. The number of male and female participants in Arman Language Institute in Ahvaz.

\begin{tabular}{lll}
\hline Participants & Experimental Group (A) & Control Group (B) \\
\hline Male & 8 & 9 \\
Female & 10 & 9 \\
Total & 18 & 18 \\
\hline
\end{tabular}

\subsection{Material}

To study the effect of self-efficacy on reading comprehension the following materials will be employed throughout the course of this study:

OPT test was used for the purpose of homogenizing the level of the learners.

Another type of the test which was used for the purpose of the study is reading comprehension ability test. This type of test was utilized as pre-test to measure the learner's preliminary knowledge of two groups.

Then a self-efficacy test was administered to the participants to determine their effective level.

Another reading comprehension test will be used as a posttest.

\subsection{General Self-efficacy Questionnaire}

This questionnaire is the Persian adaptation of the general self-efficacy scale constructed by Nezami, Schwarzer and Jerusalem [22] which includes 10 items that measures selfefficacy based on subjects' tendencies. Subjected participants indicate the degree of their agreement with each item on the basis of a 4-rank Likert graded from "I totally disagree" with a score of 1 to "I totally agree" with a score of 4 .

\subsection{Procedure}

The pre-test post- test design was employed in this study. First of all the participants was homogenized by an OPT test and randomly assigned into two groups (A group and B group). A group consists of 18 students and B group consist of 18 learners. Then the same reading comprehension ability pre-test was administered to all participants. Next a same self-efficacy test was given among all participants as pre-test to assign all students were in same rate in selfefficacy. And in Experimental Group (A group), treatment was run by researcher, so he start to teach self-efficacy to the participants. And In control group (B group), none of the above-mentioned techniques won't use by researcher. Instead, traditional reading comprehension texts were translated only. After 7 sessions, both experimental groups and control groups take the same reading comprehension ability test as a post-test.

Table 2. Data Collection Procedures.

\begin{tabular}{ll}
\hline Experimental Group (A) & Control Group (B) \\
\hline 1-Pre-test & 1-Pre-test \\
2-Regular reading instruction following & 2-Regular reading instruction \\
the course book, Treatment (seven & following the course book, no \\
weeks), self- efficacy as treatment & special reading training. \\
3-Post-test & 3-Post-test \\
\hline
\end{tabular}

According to the results of pre-test and post-test is determined that the instructions reading, through the textbook without education in seven weeks is taken.

\section{Results and Discussion}

In order to examine the difference between the experimental group and control group, when the pre- test was administered, the first step in data analysis was to score the participants' performances. To see the difference between the experimental and the control groups, the performances of control and experimental participants on reading comprehension pre-test were compared with the aid of an independent sample test on study's commencement.

Table 3. The mean comparison of experimental and control participants on the reading comprehension pre-test.

\begin{tabular}{|c|c|c|c|c|c|c|c|}
\hline & \multirow{2}{*}{$\mathbf{F}$} & \multicolumn{2}{|c|}{ Levene's Test for Equality of Variances } & \multicolumn{4}{|c|}{ t-test for Equality of Means } \\
\hline & & sig. & $\mathbf{t}$ & df & Sig. (2-tailed) & Mean Difference & Std. Error Difference \\
\hline Equal variances assumed & .631 & .432 & -.716 & 34 & .479 & -.22222 & .31020 \\
\hline Equal variances not assumed & & & -.716 & 33.511 & .479 & -.22222 & .31020 \\
\hline
\end{tabular}

Based on the post-test results, in order to see whether this difference is statistically significant, independent

sample test analysis was ran.

Table 4. The mean difference of post- test between the experimental groups and control group.

\begin{tabular}{|c|c|c|c|c|c|c|c|}
\hline & \multirow{2}{*}{$\mathbf{F}$} & \multicolumn{2}{|c|}{ Levene's Test for Equality of Variances } & \multicolumn{4}{|c|}{ t-test for Equality of Means } \\
\hline & & sig. & t & df & Sig. (2-tailed) & Mean Difference & Std. Error Difference \\
\hline Equal variances assumed & 11.683 & .002 & 4.665 & 34 & .012 & 1.33333 & .28583 \\
\hline Equal variances not assumed & & & 4.665 & 24.120 & .012 & 1.33333 & .28583 \\
\hline
\end{tabular}

$\mathrm{p}<.05$ level 
According to independent sample test results there was a statistically significant difference between the post-test results of the experimental and the control participants $(\mathrm{p}=0.012<.05)$. Figure 1 shows the mean of pre and posttest of control and experimental groups.

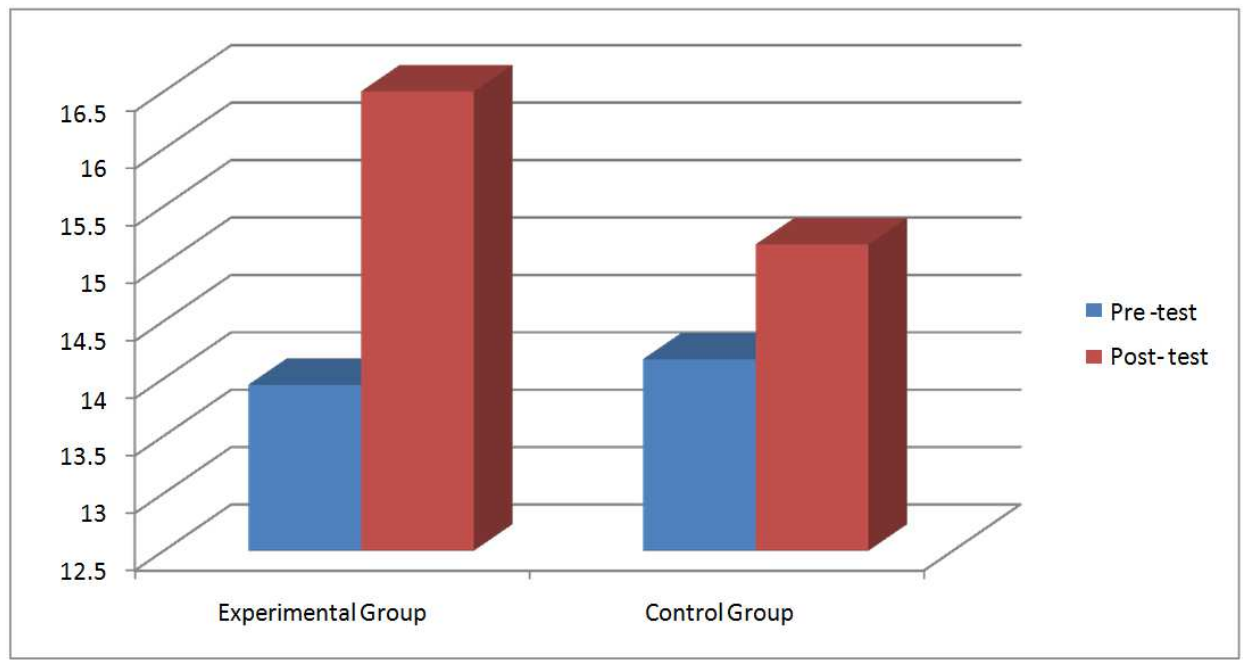

Figure 1. Pre and Post-test Means of the Experimental and control groups of this study.

Research Question 1

The results of male and female learners' self-efficacy were compared. It was needed to find out whether there was any difference between male and female learners' self- efficacy. The mean score of males and females were almost the same. To investigate whether there was any significant difference between male and female learners' self-efficacy, an independent samples t-test was run.

Table 5. Independent Samples t-test for male and female learners'self-efficacy.

\begin{tabular}{|c|c|c|c|c|c|c|c|}
\hline & \multirow{2}{*}{$\mathbf{F}$} & \multicolumn{2}{|c|}{ Levene's Test for Equality of Variances } & \multicolumn{4}{|c|}{ t-test for Equality of Means } \\
\hline & & sig. & $\mathrm{t}$ & df & Sig. (2-tailed) & Mean Difference & Std. Error Difference \\
\hline Equal variances assumed & 4.548 & 040 & 1.031 & 34 & 310 & 13003 & 12607 \\
\hline Equal variances not assumed & & & 1.013 & 28.809 & 320 & 13003 & 12837 \\
\hline
\end{tabular}

$\mathrm{p}<.05$ level

As Tables 4-6 indicated, sig was. 310 which was higher than the predetermined value of ,0.05” $(\mathrm{p}>0.05)$. This means that there was no significant difference between male and female learners' self-efficacy.

Research Question 2
The scores of males and females were analyzed separately in this table. According to independent sample test.

there wasn't a statistically significant difference between the pre-test results of males and females participants $(\mathrm{p}=802>05)$.

Table 6. Levene's Test for Equality of Variances.

\begin{tabular}{|c|c|c|c|c|c|c|c|}
\hline & \multirow{2}{*}{$\mathbf{F}$} & \multicolumn{2}{|c|}{ Levene's Test for Equality of Variances } & \multicolumn{4}{|c|}{ t-test for Equality of Means } \\
\hline & & sig. & t & df & Sig. (2-tailed) & Mean Difference & Std. Error Difference \\
\hline Equal variances assumed & 019 & 892 & .255 & 16 & 802 & 10000 & 39151 \\
\hline Equal variances not assumed & & 249 & 13.259 & .807 & 10000 & 40198 & -76670 \\
\hline
\end{tabular}

Table 7. Analysis of test scores for boys and girls.

\begin{tabular}{|c|c|c|c|c|c|c|c|}
\hline & \multirow{2}{*}{$\mathbf{F}$} & \multicolumn{2}{|c|}{ Levene's Test for Equality of Variances } & \multicolumn{4}{|c|}{ t-test for Equality of Means } \\
\hline & & sig. & t & df & Sig. (2-tailed) & Mean Difference & Std. Error Difference \\
\hline Equal variances assumed & 173 & 683 & 140 & 16 & 891 & 05000 & 35773 \\
\hline Equal variances not assumed & & & 142 & 15.741 & 889 & 05000 & 35316 \\
\hline
\end{tabular}

In other hand, the scores of males and females in post-test were analyzed separately.

According to independent sample test there wasn't a statistically significant difference between the pre-test results of males and females participants $(p=891>05)$. This means that there was no significant difference between male and female learners' reading comprehension based on gender.

\section{Discussion}

Based on the findings of the study, when reader's selfefficacy raises ones' success in reading comprehension 
increases and conversely when reader's self-efficacy reduces ones' success in reading comprehension decreases. Also, gender cannot be a factor that influences on the act of males and females. Both highly self-efficacious male and female students will have statistically significant difference in reading comprehension. So, self-efficacy and reading comprehension are related to each other. The results of this study are in conformity with studies reported by Haung and Chang [23], Ho [24], Mills et al. [25], Rahemi [26], Li and Wang [27], Hashemi and Ghanizadeh [28], Doordinejad and Afshar [29], Naseri and Zaferanieh [30] Karegar and Zamanian [31] that confirm and refer to the positive relationship between language learner and English achievement.

\section{Conclusion}

The results of the study indicated that, the experimental group improved its reading comprehension significantly at the end of the seven-week instructing, "A" group (pre-test: $x=$ 13.9444, post-test: $x=16.5000$, development: 2.5556$)$. This increases may be attributed to the instructing which this group received. As suggested by the literature (Bandura [32], Alimoradi, Jahandar and Khodabandehlou [33] Moskal \& Blachowicz, [34], Li and Wang [35] reading comprehension can be developed through improving learner's self-efficacy. There have been very few studies into the effectiveness of selfefficacy despite its obvious importance for successful learning. In conclusion, the results of this study point out that selfefficacy instruction benefits L2 learners overall, which confirms previous results (e.g., Magogwe and Oliver [36] Chen et. al., [37], cited in Rahimi and Abedini, [38] and Rahimi and Abedini [39] Hosenfeld [40] Tilfarlioglu and cgnkara [41]. These results demonstrate that even adding only a relatively time-limited explicit self-efficacy can lead to beneficial results in production for learners.

\section{Pedagogical Implications}

In light of the study's findings, it seems reasonable to accommodate the self-efficacy in class activities with a more attention given to the relationship between selfefficacy and different skills acquiring. Sometimes selfefficacy has been a neglected item of English language teaching, which has not received the attention. This negligence may be due to the lack of teachers' attention at language schools, or it may be because of time limitation in the classes. However, as this study has indicated, selfefficacy plays an important role in the ELT world, particularly in developing reading comprehension. Selfefficacy is an important concept which is considerably related to language learning. Teachers should increase their own self-efficacy beliefs in order to motivate students to improve their reading skill. Reliance of students on their capabilities can help them to cope with learning barriers. So, self-efficacy is more effective in determining and predicting the reading performance of language learners than their proficiency level. EFL learners' self-beliefs can affect their reading comprehension negatively or positively depending on the strength of their self-efficacy.

\section{Suggestions for Further Research}

As discussed above in the limitations of the study, a sevenweek period is not enough for a language skill to develop. Therefore, for future research studies, the period can be extended. The present study was conducted with only intermediate level participants, for further studies a wider scope of samples can be employed and different proficiency levels might be examined. In addition, since improving the selfefficacy is special treatment, is harder than other treatments to teach, it is better that expert of this field use to teach it.

\section{References}

[1] Alfassi M (2004). Reading to Learn: Effect of combined strategy instruction on high school students. Journal of Educational Research 97 (4) 171-184.

[2] Alimoradi, H. \& Jahandar, SH. \& Khodabandehlou, M. (2103). The impact of self-efficacy on iranian EFL learner's reading comprehension ability at pre-intermediate level. Indian Journal of Fundamental and Applied Life Sciences ISSN: 2231-6345.

[3] Alderson, J. C. (1984). Reading in a Foreign Language: A Reading Problem or a Language Problem?" In J. C. Bagheri, M. S \& Faghih, M. (2012). The Relationship between selfesteem, personality type andreading comprehension of Iranian EFL students. Theory and practice in language studies, $2(8), 1641-1650$

[4] Bandura, A. (2006). Adolescent development from an agentic perspective. In F. Pajares, \& T. Urdan (Eds.), Self- efficacy beliefs of adolescents (pp. 1-43). Greenwich, CT: Information Age Publishing.

[5] Bandura, A. (1999). Social cognitive theory: An agentic perspective. Asian Journal of Social Psychology, 2 (1), 2141. http://dx.doi.org/10.1111/1467-839X. 00024.

[6] Bandura, A. (1997). Self-efficacy: The exercise of control. New York: W. H. Freeman and Company. Bandura, A. (1986). Social foundations of thought and action: A social cognitive theory. Englewood Cliffs, NJ: Prentice Hall.

[7] Behjat, F., Yamini, M., \& Bagheri, M. S. (2012). Blended Learning: A Ubiquitous Learning Environment for Reading Comprehension. International Journal of English Linguistics, 2, 97-106. Brown, H. Douglas (2001). Teaching by Principles: An Interactive Approach to Language Pedagogy (2nd ed). Pearson ESL Press.

[8] Bachman, L. F. (1990). Fundamental Considerations in Language Testing. Oxford: Oxford University Press. Bachman, L. F. (2004). Statistical Analyses for Language Assessment. Cambridge: Cambridge University Press. Carrell, P. L. (1989). Metacognitive awareness and second language reading. The Modern Language Journal, 73 (2), 121-134.

[9] Carrell, Patricia L., Pharis, B. G., \& Liberto, J. C. (1989). Metacognitive strategy training for ESL reading. TESOL Quarterly, 23 (4), 647-678. 
[10] Freedman, L. (2006). Actions that create, actions that destroy: Practices and processes for building secondary students' reading proficiency Symposium presentation at National Reading, Los Angeles, CA.

[11] Jalilifar, A. (2010). "The effect of cooperative learning techniques on college students' reading comprehension", in System, 38: 96-108.

[12] Hafiz, F. M. \& Tudor, Ian. (1989). "Extensive reading and the development of language skills." ELT Journal, 43 (1): 413 .

[13] Huang, S. C., \& Chang, S. F. (1998). Self-efficacy in learners of English as a second language: four examples. Journal of Intensive English Studies, 12, 23-40.

[14] Lane, J., Lane, A., \& Kyprianou, A. (2004). Self-efficacy, self-esteem and their impact on academic performance. Social Behaviour and Personality, 32, 247-256.

[15] Linnenbrink, E. A., \& Pintrich, P. R. (2003). The role of selfefficacy beliefs in studentengagement and learning in the classroom. Reading and Writing Quarterly: OvercomingLearning Difficulties, 19 (2), 119-137. http://dx.doi.org/ 10.1080/10573560308223.

[16] Li, Y., \& Wang, C. (2010). An empirical study of reading self-efficacy and the use of reading strategies in the Chinese EFL context. Asian EFL Journal, 12 (2), 144-162.

[17] Naseri, M., \& Zaferanieh, E. (2012). The relationship between reading self-efficacy beliefs, reading strategy use and reading comprehension level of Iranian EFL learners. World Journal of Education, 2, 64-75.

[18] Nezami, E., Schwarzer, R., \& Jerusalem, M. (1996). Persian Adaptation (Farsi) of the General Self-Efficacy Scale. [Online] Available: http://userpage.fuberlin.de/ health/persean.htm (May 18, 2011).

[19] Oxford, R. L. (2001). Language learning strategies. In R.
Carter \& D. Nunan (Eds.), The Cambridge guide to teaching English to speakers of other language (pp. 166-172). Cambridge, UK: Cambridge University Press.

[20] Rahimi, M., Riazi, A., \& Saif, Sh. (2004). An investigation into the factors affecting the use of language learning strategies by Persian EFL learners. RCLA. CJAL, 11 (2), 31-60.

[21] Rosenfeld, P., Booth-Kewley, S., Edwards, J. E., \& Thomas, M. D. (1996). Responses on computersurveys Impression management, social desirability, and the big brother syndrome. Computers in Human Behavior, 12 (2), 263-274.

[22] Schunk, D. H. (1987). Peer models and children's behavioral change. Review of Educational Research, 57 (2), 149-174.

[23] Schwarzer, R. \& Fuchs, R. (1995). Self-efficacy and health. In Bandura, A. (ed.) Self-Efficacy in Changing Societies. New York: Cambridge University Press.

[24] Siew, M. \& Wong, L. (2005). Language learning strategies and language self-efficacy: Investigating the relationship in Malaysia. Regional Language Centre Journal, 36 (3), 245-269.

[25] Wang, C., \& Li, Y. (2010). An Empirical Study of Reading Self-efficacy and the Use of Reading Strategies in the Chinese EFL Context. The Asian EFL Journal Quarterly, 12 (2), 144-162. www.ccsenet.org/elt English Language Teaching Vol. 5, No. 11; 201270.

[26] Weinstein, C. E., \& Mayer, R. E. (1986). The teaching of learning strategies. In M. Wittrock, Handbook of Research on teaching (pp. 315-327). New York: Macmillan.

[27] Wu, C. P. (2006). The Effects of goal Orientation, Self-efficacy, and Cognitive /Metacognitive Self regulatory Strategy Use on EFL College Students' Course Achievement. Unpublished Ph D dissertation. University of Southern California.

[28] Zimmerman, B. (2000). Self-Efficacy: An Essential Motive to Learn. Contemporary Educational Psychology, 25, 82-91. 